\title{
Price Prediction Model of Demand and Supply in the Housing Market
}

\author{
Rozlin Zainal ${ }^{1}$, Fazilah Ramli1 ${ }^{1, *}$, Norpadzlihatun Manap ${ }^{1}$, Maimunah Ali $^{2}$, Narimah Kasim ${ }^{1}$, Hamidun Mohd. Noh ${ }^{1}$ and \\ Sharifah Meryam Shareh Musa ${ }^{1}$ \\ ${ }^{1}$ Construction Management Department, Faculty of Technology Management and Business, University of Tun Hussein Onn Malaysia, \\ 86400, Parit Raja, Batu Pahat, Johor, Malaysia \\ ${ }^{2}$ Management and Technology Department, Faculty of Technology Management and Business, University of Tun Hussein Onn \\ Malaysia, 86400, Parit Raja, Batu Pahat, Johor, Malaysia
}

\begin{abstract}
Over recent years, the imbalance between housing demand and supply, particularly in the highcost housing segment, led to the rapid increase in the house prices. This paper has applied the standard theory of consumer demand and supply supplemented using content analysis method to explain the trend of housing demand and supply of housing market in Malaysia. Sampling in the quantitative content analysis is carried out to achieve the objective. Property Market Status Report in the NAPIC website provide a series data for total housing demand and supply for any house type of terrace, detached, cluster and townhouse in the price range between RM50,000 to RM300,000. All data provided cover from the first quarter until the fourth quarter across the year 2006 to 2015 specifically in Peninsular Malaysia only. Each level of the house price has a different equilibrium price so that developers can use it as an indicator based on the housing type. This research will promote ways to achieve the sustainabiliy in construction output overall so that the scholars can improve the equilibrium price model proposed in order to make the Malaysian housing become an affordable.
\end{abstract}

\section{Introduction}

Specifically, in the housing development, one of the important aims is to provide an adequate supply of the housing by focussing on the actual median house price stated by the different regions [1]. Over the past five years, however, the annual completion of houses had declined considerably to 80,089 units, far below 166,000 units average net increases in the number of households' annually. This suggests an average shortage of 85,911 housing units per year between 2011 and 2015 [2]. However, the latest findings by NAPIC in the Preliminary Property Market Brief 2017 regarding to the sales performance in the unsold status for all types of housing prices are incongruent with this aim [8]. Each analysed year shows different pattern in the housing demand trend. For example, the sales performances for the housing price at RM50,000 still not achieve a 100\% sales even the total units supply is small compared to the others housing price. In some cases, the developers only develop the affordable housing price only to follow the government regulations without making a brief study on the actual demand for the location selected.

BNM (2015) also added that the housing market is not provided with an adequate supply of affordable housing especially for the middle-class income group. The gap between the housing demand and supply during year 2014 was estimated around 960,000 units across Malaysia which recorded about $50 \%$ of the shortage is faced by Sabah and Sarawak. The rest of the half percent recorded are Kuala Lumpur, followed by Pulau Pinang and Johor by having the highest shortage of affordable housing units (BNM, 2015). Contradict, Selangor is the only state found to have a surplus of an affordable housing units (BNM, 2015). To sum up from all Malaysian plans, the private sector has exceeded this set target by providing a surplus of $41 \%, 29.4 \%$, and $116 \%$ of houses over the past three consecutive Malaysia Plan periods (1991-1995, 1996-2000, and 2000-2005, respectively.

From macroeconomic aspects, the global financial crisis during 2008 lead to the massive asset purchases around the world, which fuelled the beginning of the housing boom in Malaysia. The period also saw new players entering the sector at a time when buyers view properties as investments instead of housing when they can flipped with $25 \%-30 \%$ profit on completion [2]. Not only that, introduction of the Interest Capitalisation Scheme (ICS) and Developer Interest Bearing Scheme (DIBS) by BNM had cause a fake booming real estate prices, as well as give an opportunity for speculators to invest using a smaller capital expenditures [2]. As a sequence, housing supply especially for high-cost units are booming beginning 2013 until 2015 even the sales performance for that housing type is not achieved even

\footnotetext{
* Corresponding author: fazilahramli92@yahoo.com.my
} 
half of the unit supply [1][3][8]. This is happen because the developers can still gain a high margin.

Macroeconomic and microeconomic demand and supply factors often overlap significantly toward an overflow of the high-cost housing market [5]. Basic demand factors among households which commonly associated with the demographics characteristics such as monthly income, size of household, and consumer preferences as the most influencer in the housing sales performance that always been neglected by developers [10]. Majority developers ignore the actual demand for the certain type of the housing as they only take an advantages certainly from the boost of economic activity in a place with encouraging factor migration occurred among the population [10][12].

Failure of the local planner authorities happens when the nature of housing planning only focussing on the broad housing needs instead of the local needs [11]. Ministry of Housing and Local Government clarify that the local authorities and the housing developers should do a preliminary investigation on the housing demand and supply from the data released by NAPIC before planning any new developments. Further to that, JPN reported that the construction applications for high-cost housing units approved by JPN are the highest record at $96.7 \%$, which are around 112,850 of 116,649 housing units [3]. Meanwhile, JPN recorded that only $0.4 \%$ in the approval for the low-medium cost housing construction, which only involved around 509 housing units.

\subsection{Housing oversupply factors}

In addition to the issues arise reported by the government sector, a study by [13] revealed that the availability and cost of production factors, expectations regarding to the future property demand, prices, and perceived market risk as the major contributor to the oversupply of the housing in Malaysia. Besides that, the housing developers should strive in developing the housing unit even if they are facing a low sales performances due to the low in demand and oversupply of the housing provided [10]. This matter of course complies with the fundamental law of supply, which state that a greater quantity is supplied at the higher prices [6]. In line with that study, another study found that the planning mechanisms especially via the development plan and control involved in the housing development process are vital to achieve the effectiveness of the housing supply system in Malaysia [10].

From the perspective of supplying an adequate supply of housing, recent research revealed that the supplying adequate housing cannot be done by only looking at the total demanded [9]. According to the study, generally the housing developers are not associated the housing development with the affordability level and housing choice by the population. Unresolved unsold units are happen since the housing developers is only supply more without taking consideration for the genuine demand [7]. Latest study done by [14] identified that the mismatched between supply and demand contribute to several problem. Surplus of the housing supply lead to the construction wastage and of course has an impact on the cost and the economic aspects. Meanwhile, the shortage of the housing supply can lead to the increasing of the house price [14].

\section{Methodology}

In order to develop an equilibrium price framework in the housing market, secondary data such as total demand and supply for a 10-year period from 2006 to $2015 \mathrm{had}$ been analysed. Raw data obtained from NAPIC will be analysed using regression method in the SPSS software to find $a$ and $\beta$ values. Next, both values will be substituted into the equation as shown in the following equation:

$$
\begin{aligned}
& Q_{\mathrm{D}}=\mathrm{a}-\beta P \\
& Q_{\mathrm{s}}=\mathrm{a}+\beta P
\end{aligned}
$$

\section{Result and Discussion}

Table 1 shows the results of the regression analysis undertaken. $\alpha$ value representing the balance of demand and supply of housing, meanwhile the $\beta$ value represent the equilibrium price of housing. The $\alpha$ and $\beta$ value were substituted into the equation (1) and (2) to develop the housing prediction model.

Table 1. Results of linear regression analysis

\begin{tabular}{|l|c|c|c|c|}
\hline \multirow{2}{*}{ House Price } & $\begin{array}{c}\text { Type of } \\
\text { Dependent } \\
\text { Variables }\end{array}$ & $\begin{array}{c}\boldsymbol{\beta} \\
\text { Value }\end{array}$ & $\begin{array}{c}\boldsymbol{\alpha} \\
\text { Value }\end{array}$ & $\begin{array}{c}\text { r- } \\
\text { Value }\end{array}$ \\
\hline \multirow{2}{*}{$\begin{array}{l}\text { RM50,000- } \\
\text { RM100,000 }\end{array}$} & Demand & 0.774 & -17276.8 & 0.774 \\
\cline { 2 - 5 } & Supply & 0.782 & -12426.0 & 0.782 \\
\hline \multirow{2}{*}{$\begin{array}{l}\text { RM100,001- } \\
\text { RM150,000 }\end{array}$} & Demand & 0.067 & 26206.4 & 0.067 \\
\cline { 2 - 5 } RM150,001- & Supply & 0.028 & 15258.4 & 0.028 \\
\cline { 2 - 5 } RM200,000 & Supply & 0.019 & 22928.0 & 0.019 \\
\hline \multirow{2}{*}{$\begin{array}{l}\text { RM200,001- } \\
\text { RM250,000 }\end{array}$} & Demand & 0.321 & 47910.8 & 0.321 \\
\cline { 2 - 5 } & Supply & 0.366 & 40136.7 & 0.366 \\
\hline RM250,001- & Demand & 0.677 & 74535.8 & 0.677 \\
\cline { 2 - 5 } RM300,000 & Supply & 0.685 & 55783.7 & 0.685 \\
\hline
\end{tabular}

Calculations done in this research using $\beta$ value in the Table 4.14 shows that each house price that had been analysed are not having a huge subtle differences between $\beta$ value for demand and supply. House price at range RM100,000 - RM150,000 recorded the highest difference between beta value for demand and supply around 0.095 , meanwhile, house price at range RM50,000 until RM100,000 and RM250,000 RM300,000 recorded the lowest difference of the $\beta$ beta value for demand and supply around 0.008 . The slight subtle differences between both $\beta$ values indicates the 
changes of each demand and supply on house prices do not depend on the house price offered factor. In this case, the findings are too contradict with the fundamental law of demand and supply which state that price is the main factor in the demand and supply mechanism. However, the findings seem in line with Grimes and Aitken (2010) which state that the house price is not as the biggest factor that affects the volatility of demand and supply in the housing market.

\subsection{Housing Price Prediction Equation}

The new equations are developed using the previous equation (1) and (2) before developing the housing prediction model. The equation (3) shows the total demand for housing price range between RM50,001 RM100,000 need to be increase about $77.4 \%$ in response to $1 \%$ increase in price, meanwhile, the equation (4) shows the total supply need to be increase about $78.2 \%$ in response to $1 \%$ increase in price.

$$
\begin{aligned}
& Q_{\mathrm{D}}=0.774 P-17276.8 \\
& Q_{\mathrm{s}}=0.782 P-12426.0
\end{aligned}
$$

Secondly, the equation (5) shows the total demand for housing price range between RM100,001 RM150,000 need to increase about $6.7 \%$ in response to $1 \%$ increase in price, meanwhile, the equation (6) shows the total supply need to increase about $2.8 \%$ in response to $1 \%$ increase in price.

$$
\begin{aligned}
& Q_{\mathrm{D}}=0.067 P+26206.4 \\
& Q_{\mathrm{s}}=0.028 P+15258.4
\end{aligned}
$$

Thirdly, the equation (7) shows the total demand for housing price range between RM150,001 RM200,000 need to increase about $1.9 \%$ in response to $1 \%$ increase in price, meanwhile, the equation (8) shows the total supply need to increase about $3.0 \%$ in response to $1 \%$ increase in price.

$$
\begin{aligned}
& Q_{\mathrm{D}}=0.019 P+22928.0 \\
& Q_{\mathrm{s}}=0.003 P+16830.7
\end{aligned}
$$

Fourthly, the equation (9) shows the total demand for housing price range between RM200,001 RM250,000 need to increase about $32.1 \%$ in response to $1 \%$ increase in price, meanwhile, the equation (10) shows the total supply will increase about $36.6 \%$ in response to $1 \%$ increase in price.

$$
\begin{aligned}
& Q_{\mathrm{D}}=0.321 P+47910.8 \\
& Q_{\mathrm{s}}=0.366 P+40136.7
\end{aligned}
$$

Lastly, the equation (11) shows the total demand for housing price range between RM250,001 RM300,000 will decrease about $67.7 \%$ in response to $1 \%$ increase in price, meanwhile, the equation (12) shows the total supply will increase about $68.5 \%$ in response to $1 \%$ increase in price.

$$
\begin{aligned}
& Q_{\mathrm{D}}=0.677 P+74535.8 \\
& Q_{\mathrm{s}}=0.685 P+55783.7
\end{aligned}
$$

\begin{tabular}{|c|c|c|c|}
\hline House Price & \multicolumn{2}{|c|}{ Quantity Schedule } & $\begin{array}{c}\text { Equilibrium } \\
\text { Price } \\
\end{array}$ \\
\hline \multirow{2}{*}{$\begin{array}{l}\text { RM50,000- } \\
\text { RM100,000 }\end{array}$} & Demand & -64208.29 & \multirow{2}{*}{ RM60,635.00 } \\
\hline & & & \\
\hline \multirow{2}{*}{$\begin{array}{l}\text { RM100,001- } \\
\text { RM150,000 }\end{array}$} & Demand & 33927.62137 & \multirow{2}{*}{$\begin{array}{r}\text { RM115,242.1 } \\
1 \\
\end{array}$} \\
\hline & Supply & 18485.1 & \\
\hline \multirow{2}{*}{$\begin{array}{l}\text { RM150,001- } \\
\text { RM200,000 }\end{array}$} & Demand & 15687.45625 & \multirow{2}{*}{$\begin{array}{r}\mathrm{RM} 381,081.2 \\
5 \\
\end{array}$} \\
\hline & Supply & 4375 & \\
\hline \multirow{2}{*}{$\begin{array}{l}\text { RM200,001- } \\
\text { RM250,000 }\end{array}$} & Demand & 103366.0467 & \multirow{2}{*}{$\begin{array}{r}\text { RM172,757.7 } \\
8\end{array}$} \\
\hline & Supply & 23092.64675 & \\
\hline \multirow{2}{*}{$\begin{array}{l}\text { RM250,001- } \\
\text { RM300,000 }\end{array}$} & Demand & 1661432.263 & \multirow{2}{*}{$\begin{array}{r}\mathrm{RM} 234,401.0 \\
0\end{array}$} \\
\hline & Supply & 1549864.863 & \\
\hline
\end{tabular}

\subsection{Housing price prediction modelling}

Table 2 shows the list of each housing equilibrium price according to the different level of price categorised based on the equation formed in the equation (3) until (12).

Table 2. Housing Equilibrium Price According to the Level of Price Categorised

Figures 1, 2, 3, 4 and 5 presented is to show clearly about the demand and supply mechanism analysis according to the economic analysis side after the process of identifying the housing equilibrium price in the Table 2. Based on economic theory, all the figures show explicitly the analysis of demand and supply mechanisms. According to all these diagrams, price equilibrium will occur at the intersection of the cross between the supply schedule and the demand schedule. If we make a comparison using all figures, supply schedule (SS) would not change but the demand schedule (DD) will change.

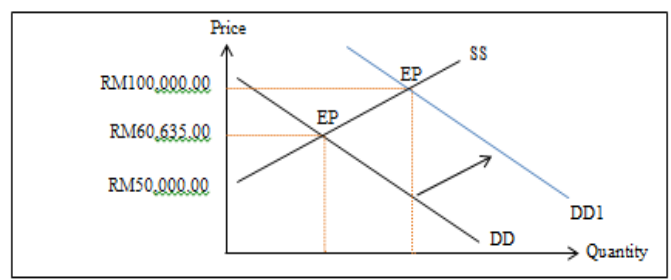

Figure 1: Equilibrium Intersection Point in Price Range RM50,000 until RM100,000 


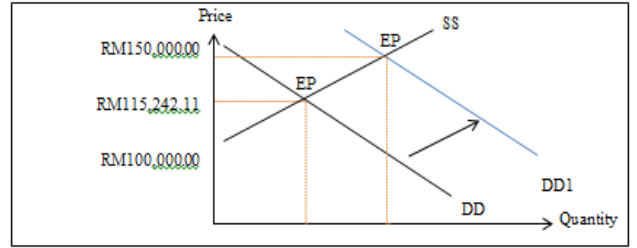

Figure 2: Equilibrium Intersection Point in Price Range RM100,000 until RM150,000

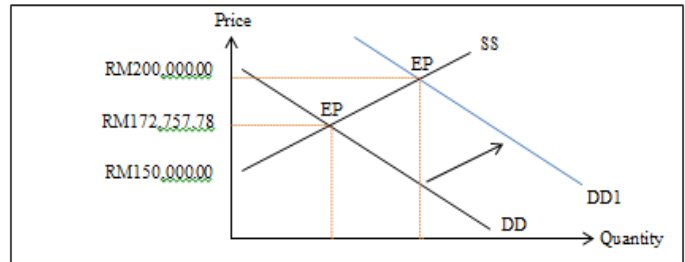

Figure 3: Equilibrium Intersection Point in Price Range RM150,000 until RM200,000

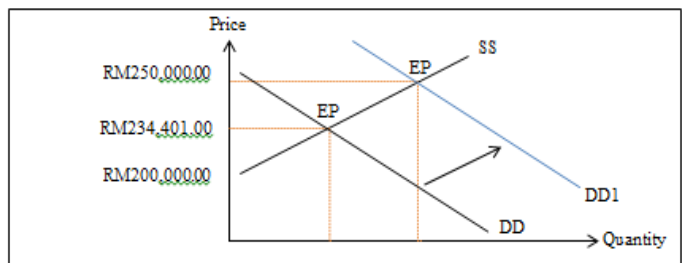

Figure 4: Equilibrium Intersection Point in Price Range RM200,000 until RM250,000

The housing equilibrium prices (EP) presented in Figure 1 until 4 seem not too reliable with the housing price boundary. It is not logic for the developers to set the house price lower than housing price market. Even the aim for developing the affordable housing is more to fill the demand for housing demand especially for the middle-class income, the cost construction burden cannot faced by housing developers only. In this case, developers start to focus on rising the housing price to in line with the rising of the construction cost. An increase of cost of production will reduces the revenue of the supplier. When the cost of production for building houses is higher, developers will cut down the supply of houses.

Eventually, this will affect the market equilibrium because equilibrium of price and quantity will no longer the same after the increased of housing price. In other hand, an increase in the housing equilibrium price to the actual housing price market is not interrupt the supply schedule because the point for the changes of total supply still lie on it.

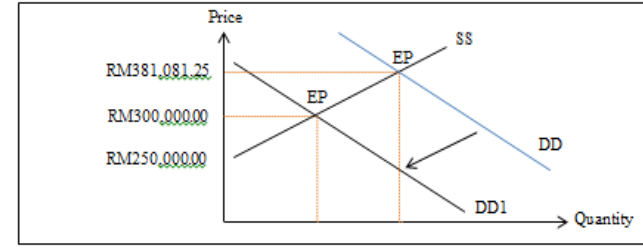

Figure 5: Equilibrium Intersection Point in Price Range RM250,000 until RM300,000

However, in a certain cases as shown in the Figure 5 , the housing equilibrium price is identified above than the actual housing market. Supposed that the developers are set a higher price for the houses because they want to earn more while the income of the citizen remain the unchanged. An increase in price of houses itself will only result a movement along the curve whereby the quantity of demand for the houses will decrease. This happen because some of the buyers are not affordable to buy the houses after the changes because their income is still remain unchanged. However, in a meantime, increases the housing equilibrium price to the actual housing price market totally interrupt the demand schedule because the points for the changes of total demand are not lie on it.

\section{Conclusion}

Housing demand and supply must be in a balance state to get the equilibrium price in the housing market. To get through this, two main determinants from demand side and two main determinants from supply side that can be used as booster to balance the housing market. The housing equilibrium price is determined to minimize the homeownerships issue among Malaysian middle-class income. Eventually, the equilibrium price and the equilibrium quantity will no longer the same after the increasing of the housing price. Consumer surplus will happen if the house price is above the equilibrium price, meanwhile the developer surplus will happen if the house price is below the equilibrium price point.

\section{References}

1. Bank Negara Malaysia (BNM). Financial reporting for Islamic banking institutions (2016). Retrieved on March 10, 2016, from

http://www.bnm.gov.my/guidelines/01 banking/02 f inancial reporting/Financial Reporting for Islami c Banking Institutions.pdf

2. Cagamas Holdings Berhad.. Housing the Nation: Policies, Issues and Prospects. Kuala Lumpur: Cagamas Holdings (2013).

3. Jabatan Perumahan Negara (JPN). Laporan perangkaan Perumahan. Kuala Lumpur: Kementerian Kesejahteraan Bandar, Perumahan dan Kerajaan Tempatan. (2016) 
4. Cagamas Holdings Berhad. Housing the Nation: Policies, Issues and Prospects. Kuala Lumpur: Cagamas Holdings. (2013)

5. M. I. Juma. The effect of macro-economic variables on growth in real estate investment in Kenya. Unpublished MSc. Finance Research Project. (2014)

6. R. A. Majid, R. Said, J. T. S. Chong. Assessment of Bubble in the Malaysian Housing Market. Planning Malaysia Journal, 15(3). (2017).

7. R. Mourouzi-Sivitanidou. Office rent processes: the case of US metropolitan markets. Real Estate Economics, 30(2), pp. 317-344. (2002)

8. N/A.Soft property market in 2017: Buyers old to focus on second hand homes. (2017). TheStar Online. Retrieved on August 15, 2017, from https://www.pressreader.com/malaysia/the-starmalaysia starbiz/20170324/281586650423032

9. National Property Information Centre (NAPIC). Market Status Report (2015). Kuala Lumpur: Valuation and Property Services Department. (2015) Retrieved on December 5, 2015, from http://napic.jpph.gov.my/portal/web/guest/publicatio $\underline{\mathrm{n}}$

10. C. Nicol. The Formulation of Local Housing Strategies: A Critical Evaluation. England: Ashgate. (2002).

11. A. Rameli, F. Johar. The management of housing supply in Malaysia: Incorporating market mechanisms in housing planning process. Department of Urban and Regional Planning Faculty of Built Environment, Universiti Teknologi Malaysia, Johor Bahru, Malaysia. (2006)

12. A. Rameli. Land use planning system and housing development process in Malaysia (Doctoral dissertation, Universiti Teknologi Malaysia). (2009).

13. S. Salleh. Faktor Yang Dipertimbangkan Dalam Menentukan Harga Jualan Rumah Oleh Pemaju Perumahan: Kajian Di Negeri Kedah Dan Perlis. Kertas Penyelidikan Jabatan Penilaian dan Perkhidmatan Harta Negeri Perlis.(2008).

14. N. Yahya. Low-Cost Public Housing: Fulfilling the Basic Needs and Lifestyles. In Seminar on Accessibility to Basic Needs. (2003).

15. N. Y. Zainun, F. M. Ghazali, M. M. Sallehudin. Prediction of Low Cost Housing Demand in Malaysia Using ARIMA Model. In MATEC Web of Conferences (47). (2016) 